Sierpińska Lidia. Circumstances of infection with HCV in selected Polish provinces. Journal of Education, Health and Sport. 2021;11(2):41-52. eISSN 2391-8306. DOI http://dx.doi.org/10.12775/JEHS.2021.11.02.005

https://apcz.umk.pl/czasopisma/index.php/JEHS/article/view/JEHS.2021.11.02.005

https://zenodo.org/record/4539996

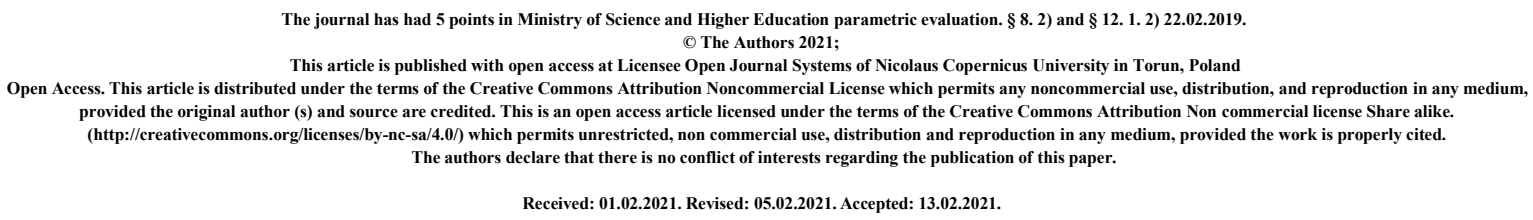

\title{
Circumstances of infection with HCV in selected Polish provinces
}

\section{Lidia Sierpińska}

a 1 Military Clinical Hospital with Polyclinic, Independent Public Health Care Unit, Al. Racławickie 23, 20-049 Lublin, Poland

Address for correspondence:

1 Military Clinical Hospital with Polyclinic, Independent Public Health Care Unit, Al. Racławickie 23, 20-049

Lublin, Poland, Poland. Fax. +48 261183277

E-mail: sierpinska1@wp.pl (L. Sierpińska)

Abstract

Introduction. In Poland, approximately 730,000 people are infected with hepatitis $\mathrm{C}$ virus (HCV), which is nearly $2 \%$ of the total population, and about 170 million worldwide - $3 \%$ of the global population. Approximately $70-80 \%$ people infected with hepatitis $\mathrm{C}$ virus develop chronic hepatitis. Knowledge of the circumstances associated with the risk of infection with $\mathrm{HCV}$ is very important in the prophylaxis of hepatitis C.

Materials and Method. The study was conducted during August 2014 - May 2018 in group of 220 patients infected with HCV by the method of a diagnostic survey, using an author-constructed questionnaire.

Results. The majority of respondents $(138 ; 62.7 \%)$ did not know the circumstances of infection with $\mathrm{HCV}$, whereas more than $1 / 3$ of them $(82 ; 37.3 \%)$ had knowledge concerning their infection. The respondents reported that the infection could have been mainly associated with a surgical procedure, followed by blood transfusion. The remaining circumstances of infection were: dental treatment, childbirth, organ transplantation, dialysis, treatment in a 
conservative ward, occupational exposure, plasmapheresis, as well as tattoo and narcotic injection. Self-reported state of respondents' knowledge concerning hepatitis $\mathrm{C}$ was mainly on the mean level $(160 ; 72.7 \%)$. About $3 / 4$ of respondents $(173 ; 78.6 \%)$ did not consider themselves to be disabled due to hepatitis C.

Conclusions. Health education is recommended in the population of adults about the risk of contracting $\mathrm{HCV}$ in treatment facilities and other places, where there is the transmission of blood-borne infections, as well as concerning the essence of chronic hepatitis C.

Key words: circumstances of HCV infection, hepatitis $C$

\section{Introduction}

Hepatitis $\mathrm{C}$ is among priorities of the national health services in Poland and worldwide in the area of contagious diseases. The World Health Organization considered hepatitis $\mathrm{C}$ as one of the greatest global epidemiological risks, which is evidences by the adopted strategy 'Global health sector strategy on viral hepatitis 2016-2021' [1].

The etiologic factor of hepatitis $\mathrm{C}$ is the hepatitis $\mathrm{C}$ virus (HCV). $\mathrm{HCV}$ is transmitted through blood, and proliferates (replicates) mainly in the hepatocytes, as well as in other organs, such as: spleen, pancreas, adrenal glands, brain, bone marrow, thyroid gland, lymph nodes, peripheral blood mononuclear cells (lymphocytes, monocytes, macrophages) [2].

An infection with HCV most often takes place in connection with medical procedures performed in treatment facilities [3]. The main risk of infection is associated with: transfusion of blood and/or blood products, organ transplantation (before the year 1992), surgical procedures and endoscopy, childbirth, haemodialysis, intravenous injections and dental treatments [4]. Infection with $\mathrm{HCV}$ may occur while performing aesthetic medicine procedures, e.g. tattoo or piercing, and during cosmetic services, such as manicure or pedicure.

Based on epidemiological studies carried out in Poland in 2009-2012 it has been estimated that during this period in the population of adults approximately 730,000 people were infected with hepatitis $\mathrm{C}$ virus ( $2 \%$ of the total population). Estimation data indicate that 170 million people worldwide (3\% of the global population) are infected with $\mathrm{HCV}[5,6,7]$. It 
should be emphasized that the population group who are unaware of $\mathrm{HCV}$ infection is difficult to assess.

Hepatitis $\mathrm{C}$ is a chronic disease which, when untreated, may lead to hepatocellular carcinoma. An important aspect in the prophylaxis of hepatitis $\mathrm{C}$ is awareness of the society concerning the risk of infection in treatment facilities, the sector of services with an increased risk of transmission of blood-borne infections, or other circumstances associated with contact with blood.

\section{Objective}

The aim of the study was recognition of the circumstances of infection with hepatitis $\mathrm{C}$ virus in Polish adult population.

\section{Materials and Method}

The study included a group of 220 patients infected at different times with HCV. The respondents' age ranged between 18-87. In the study group the percentage of females was slightly higher than that of males $-52.3 \%$ (115) and 47.7\% (105), respectively.

The selection of respondents for the study was purposeful. The study covered patients staying in medical facilities, with the consent of their managers, and students of the Higher School in Radom, members of their families and close persons, who expressed consent to participate in the research.

The study group were patients treated in 7 hospitals located in 4 provinces in Poland. The basic criterion for qualification into the study group was hepatitis $\mathrm{C}$ confirmed by a medical diagnosis. The study was conducted during the period from August 2014 - May 2018. Consent for the study was obtained from the academic Senate of the Higher School in Radom (No. 8/2014).

The study was carried out by the method of a diagnostic survey. The research instrument was a standardized author-constructed questionnaire, which contained, among others, items pertaining to socio-demographic data, such as: gender, age, education level, and marital status. The questionnaire also contained items concerning: circumstances of infection with $\mathrm{HCV}$, self-reported level of knowledge on hepatitis $\mathrm{C}$, well-being of persons infected with $\mathrm{HCV}$ from the aspect of disability, and atmosphere in the family of infected persons.

The results of the study were presented in the form of percentages and numbers. Statistical analysis was performed in order to detect possibly occurring relationships, using the non-parametric Pearson's chi-squared test. The $p$ values $<0.05$ were considered statistically significant. Statistical analysis was performed by means of the statistical software StatSoft Statistica 12.0 PL, and the Microsoft Office suite. 


\section{Results}

Slightly more females than males participated in the study - 52.3\% and $47.7 \%$, respectively. The largest number of respondents were aged 51-65 $(93 ; 42.3 \%)$, whereas the percentage of the youngest respondents aged 18-35 was the lowest $(15 ; 6.8 \%)$. The respondents' mean age was $54.7 \pm 12.69$, the youngest respondent was aged 18 , while the oldest - 87 .

Data concerning the education level showed that the percentage of respondents who had primary vocational education and secondary school education were similar: $38.2 \%(84)$ and $37.3 \%$ (82), respectively. Respondents with higher education constituted $15.0 \%$ (33), while the percentage of those who had primary education was the lowest $-9.5 \%$ (21). It was confirmed that the percentage of urban inhabitants was twice as high as that of rural inhabitants $-66.8 \%$ (147), and 33.2\% (77), respectively. The largest number of respondents were in a marital relationship - 47.7\% (105). The percentage of respondents who were widowed and that of never married were nearly the same: $18.6 \%$ (41) and $18.2 \%$ (40), respectively, whereas the percentage of those widowed was $13.6 \%$ (30). The respondents were also asked about their occupational activity (Fig. 1).

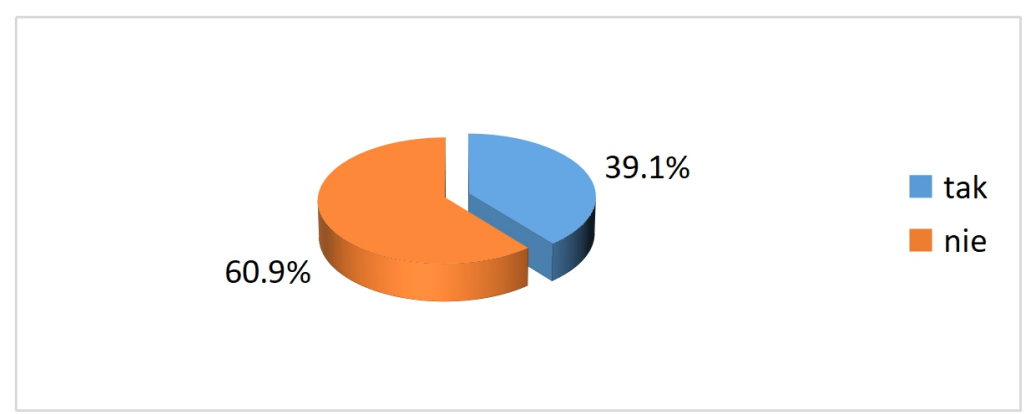

Figure 1. Respondents' occupational activity.

The majority of respondents were occupationally inactive $-60.9 \%$ (134). For this group the main source of maintenance was disability pension $-64.9 \%$ (87) and retirement pension $-23.1 \%$ (31). Some respondents experienced problems with finding employment $3.6 \%(8)$, and received an unemployment benefit. A part of the respondents $(86 ; 39.1 \%)$ worked within various types of employment contracts.

It was considered very important to recognize whether the respondents were aware in what circumstances they have become infected with hepatitis $\mathrm{C}$ virus (Tab. 1, Fig. 2). 
Table 1. Respondents' state of knowledge concerning circumstances of contracting HCV infection.

\begin{tabular}{|c|c|c|}
\hline \multicolumn{2}{|c|}{$\begin{array}{c}\text { Respondents' knowledge } \\
\text { concerning circumstances of } \\
\text { infection with HCV: }\end{array}$} & Total \\
\hline \multirow{2}{*}{ Yes } & $\mathrm{n}$ & 82 \\
\cline { 2 - 3 } & $\%$ & $37.3 \%$ \\
\hline \multirow{2}{*}{ No } & $\mathrm{n}$ & 138 \\
\cline { 2 - 3 } & $\%$ & $62.7 \%$ \\
\hline \multirow{2}{*}{ Total } & $\mathrm{n}$ & 220 \\
\cline { 2 - 3 } & $\%$ & 100.0 \\
\hline
\end{tabular}

The majority of respondents $(138 ; 62.7 \%)$ mentioned that they did not know the circumstances of infection with $\mathrm{HCV}$, and more than $1 / 3$ of them $(82 ; 37.3 \%)$ did have knowledge concerning this issue.

Based on the analysis of the collected research material it was found in what circumstances the respondents have become infected with HCV (Tab. 2).

Table 2. Circumstances of infection with HCV in respondents' opinions.

\begin{tabular}{|c|c|c|}
\hline \multicolumn{2}{|l|}{ Circumstances of infection: } & \multirow{2}{*}{$\begin{array}{l}\text { Total } \\
20\end{array}$} \\
\hline \multirow{2}{*}{ during surgical procedure } & $\mathrm{n}$ & \\
\hline & $\%$ & $24.4 \%$ \\
\hline \multirow{2}{*}{ during dental treatment } & $\mathrm{n}$ & 7 \\
\hline & $\%$ & $8.5 \%$ \\
\hline \multirow{2}{*}{ in association with blood transfusion } & $\mathrm{n}$ & 13 \\
\hline & $\%$ & $15.9 \%$ \\
\hline \multirow{2}{*}{ during childbirth } & $\mathrm{n}$ & 5 \\
\hline & $\%$ & $6.1 \%$ \\
\hline \multirow{2}{*}{$\begin{array}{l}\text { during hospital treatment in a conservative } \\
\text { ward }\end{array}$} & $\mathrm{n}$ & 4 \\
\hline & $\%$ & $4.9 \%$ \\
\hline \multirow{2}{*}{ in association with tattoo } & $\mathrm{n}$ & 2 \\
\hline & $\%$ & $2.4 \%$ \\
\hline \multirow{2}{*}{ in association with organ transplantation } & $\mathrm{n}$ & 5 \\
\hline & $\%$ & $6.1 \%$ \\
\hline \multirow{2}{*}{ narcotic injection } & $\mathrm{n}$ & 2 \\
\hline & $\%$ & $2.4 \%$ \\
\hline \multirow{2}{*}{$\begin{array}{c}\text { occupational exposure ( } 2 \text { nurses, } 2 \text { hospital } \\
\text { orderlies) }\end{array}$} & $\mathrm{n}$ & 4 \\
\hline & $\%$ & $4.9 \%$ \\
\hline \multirow{2}{*}{ dialysis } & $\mathrm{n}$ & 5 \\
\hline & $\%$ & $6.1 \%$ \\
\hline plasmapheresis (blood donation) & $\mathrm{n}$ & 1 \\
\hline
\end{tabular}




\begin{tabular}{|c|c|c|} 
& $\%$ & $1.2 \%$ \\
\hline \multirow{2}{*}{ in other circumstances } & $\mathrm{n}$ & 14 \\
\cline { 2 - 3 } & $\%$ & $17.1 \%$ \\
\hline \multirow{2}{*}{ Total } & $\mathrm{n}$ & 82 \\
\cline { 2 - 3 } & $\%$ & 100.0 \\
\hline
\end{tabular}

Analysis of data concerning the circumstances of infection indicated that the circumstances reported by the examined patients varied. Nearly one-fourth of this group of respondents mentioned that the fact of infection might have occurred 'during surgical procedure' $-24.4 \%$ (20), followed by those who mentioned 'in association with blood transfusion' $-15.9 \%$ (13). The remaining circumstances which could have been the cause of infection were reported by the groups of respondents smaller than $10 \%$. These circumstances were as follows: 'during dental treatment' $-8.5 \%$; 'during childbirth', 'in association with organ transplantation', and 'during dialysis' - 6.1\% each; 'during hospital treatment in conservative ward', and 'in association with occupational exposure' $-4.9 \%$ each; 'narcotic injection', and 'in association with tattoo' $-2.4 \%$ each; and 'plasmapheresis' $-1.2 \%$.

Respondents were also asked about their knowledge concerning the duration of the hepatitis C disease (Tab. 3).

Table 3. Duration of the disease among respondents.

\begin{tabular}{|c|c|c|}
\hline \multirow{2}{*}{ Duration of the disease (years): } & Total \\
\hline \multirow{2}{*}{$1-5$} & $\mathrm{n}$ & 44 \\
\cline { 2 - 3 } & $\%$ & $20.0 \%$ \\
\hline \multirow{2}{*}{$6-10$} & $\mathrm{n}$ & 57 \\
\cline { 2 - 3 } & $\%$ & $25.9 \%$ \\
\hline \multirow{2}{*}{$11-20$} & $\mathrm{n}$ & 86 \\
\cline { 2 - 3 } & $\%$ & $39.1 \%$ \\
\hline \multirow{2}{*}{$>20$} & $\mathrm{n}$ & 33 \\
\cline { 2 - 3 } & $\%$ & $15.0 \%$ \\
\hline \multirow{2}{*}{ Total } & $\mathrm{n}$ & 220 \\
\cline { 2 - 3 } & $\%$ & 100.0 \\
\hline
\end{tabular}

The largest group of respondents $(86 ; 39.1 \%)$ admitted that the duration of their disease was within the range 11-20 years. One-fourth of respondents $(57 ; 25.9 \%)$ have been ill for 6-10 years, whereas one-fifth of patients in the study $(44 ; 20.0 \%)$ mentioned the period of 1 - 5 years. The smallest number of respondents reported the duration of illness of more than 20 years $(33 ; 15.0 \%)$. More than a half of the respondents received treatment due to 
hepatitis C $(136 ; 61.8 \%)$, while $38.2 \%$ of respondents (84) were not treated for chronic hepatitis $\mathrm{C}$.

The respondents' self-reported knowledge concerning hepatitis C was also considered in the study. The following categories of evaluation were adopted: very high, high, mediocre, low, and very low.

Relationships between self-reported knowledge concerning hepatitis $\mathrm{C}$ and respondent's age were analysed using Spearman's rank correlation coefficient and presented in Table 4, while Table 2 demonstrates the-results.

Table 4. Respondents' age according to self-reported knowledge concerning hepatitis.

\begin{tabular}{|c|c|c|c|c|c|c|c|c|c|}
\hline $\begin{array}{l}\text { Self-reported } \\
\text { knowledge } \\
\text { concerning hepatitis } \\
\text { C: }\end{array}$ & $\mathrm{N}$ & $\%$ & $\mathbf{M}^{*}$ & $\mathrm{SD}^{*}$ & $\mathrm{Me}^{*}$ & Min.* & Max.* & $\begin{array}{l}\text { Spearman's } \\
\text { rho }\end{array}$ & $\mathrm{p}$ \\
\hline very high & 5 & 2.3 & 53.6 & 13.1 & 58.0 & 31.0 & 65.0 & \multirow{5}{*}{$\mathrm{R}=0.03$} & \multirow{5}{*}{0.698} \\
\hline high & 27 & 12.3 & 55.4 & 11.5 & 57.0 & 27.0 & 82.0 & & \\
\hline mediocre & 160 & 72.7 & 54.3 & 12.8 & 56.0 & 18.0 & 87.0 & & \\
\hline low & 25 & 11.4 & 57.1 & 14.2 & 59.0 & 27.0 & 85.0 & & \\
\hline Very low & 3 & 1.4 & 51.3 & 10.4 & 48.0 & 43.0 & 63.0 & & \\
\hline
\end{tabular}

*M-mean, SD-standard deviation, Me-median, Min.-Max. - minimum-maximum

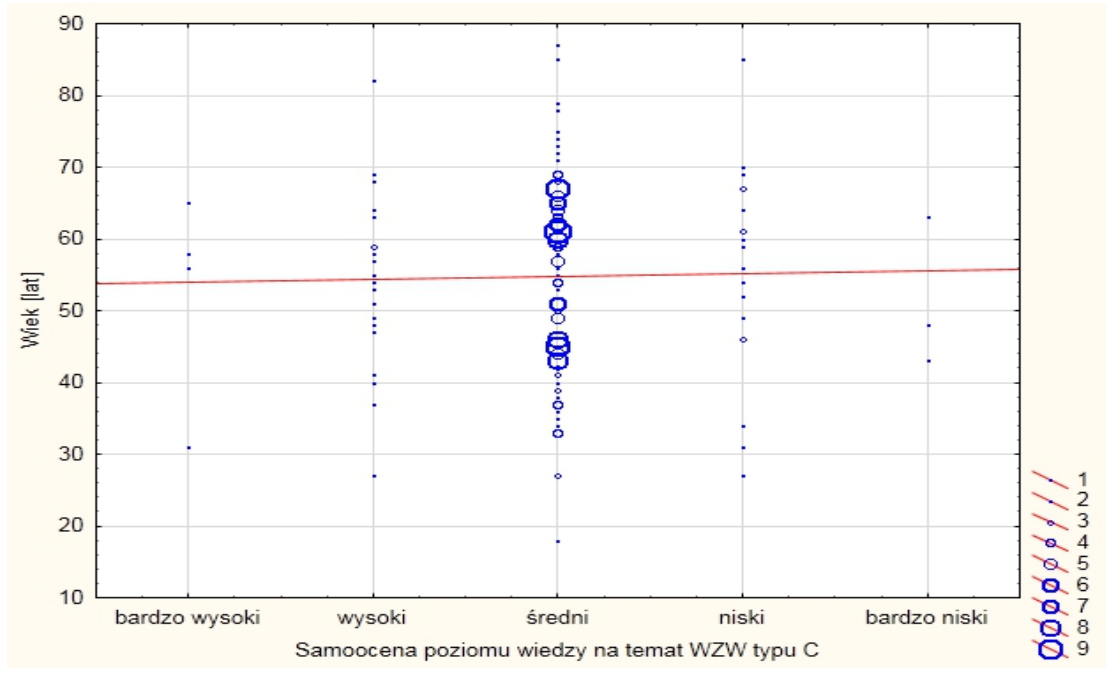

Figure 2. Distribution of respondents' age according to levels of self-reported knowledge.

As many as $72.7 \%$ of respondents (160) reported that they had a mediocre level of knowledge concerning hepatitis $\mathrm{C}-$ mean age 54.3. The youngest patient was aged 18, whereas the oldest -87 ; median -56.0 . The second position was occupied by respondents who reported that their knowledge concerning hepatitis C was on a 'high' level - 12.3\% (27), followed by a 'low' level - 11.4\% (25). Few respondents evaluated their knowledge as 'very high' $-2.3 \%(5)$ - the youngest of them was aged 31, whereas the oldest - 65 . A 'very low' level of knowledge concerning hepatitis $\mathrm{C}$ was indicated by $1.4 \%$ of respondents $(3)-$ the 
youngest of them was aged 43, and the oldest - 65. The relationships obtained were statistically insignificant ( $\mathrm{p}>0.05)$, and the correlation was slightly positive $(\mathrm{R}=0.03)$.

Relationships between level of knowledge concerning hepatitis $\mathrm{C}$ and duration of the disease were analysed by means of Spearman's rank correlation coefficient, presented in Table 5, and Figure 3 demonstrates the results.

Table 5. Duration of the disease according to the level of self-reported knowledge concerning hepatitis C.

\begin{tabular}{|c|c|c|c|c|c|c|c|c|c|}
\hline $\begin{array}{l}\text { Self-reported } \\
\text { knowledge } \\
\text { concerning hepatitis } \\
\text { C: }\end{array}$ & $\mathrm{N}$ & $\%$ & $\mathbf{M}$ & SD & Me & Min & Max & $\begin{array}{l}\text { Spearman } \\
\text { s rho }\end{array}$ & $\mathrm{p}$ \\
\hline very high & 5 & 2.3 & 25.6 & 8.6 & 26.0 & 16.0 & 39.0 & \multirow{5}{*}{$\mathrm{R}=0.04$} & \multirow{5}{*}{0.512} \\
\hline high & 27 & 12.3 & 10.1 & 5.8 & 9.0 & 2.0 & 23.0 & & \\
\hline mediocre & 160 & 72.7 & 12.5 & 8.7 & 11.0 & 1.0 & 60.0 & & \\
\hline low & 25 & 11.4 & 14.8 & 10.5 & 13.0 & 3.0 & 40.0 & & \\
\hline very low & 3 & 1.4 & 15.3 & 4.7 & 17.0 & 10.0 & 19.0 & & \\
\hline
\end{tabular}

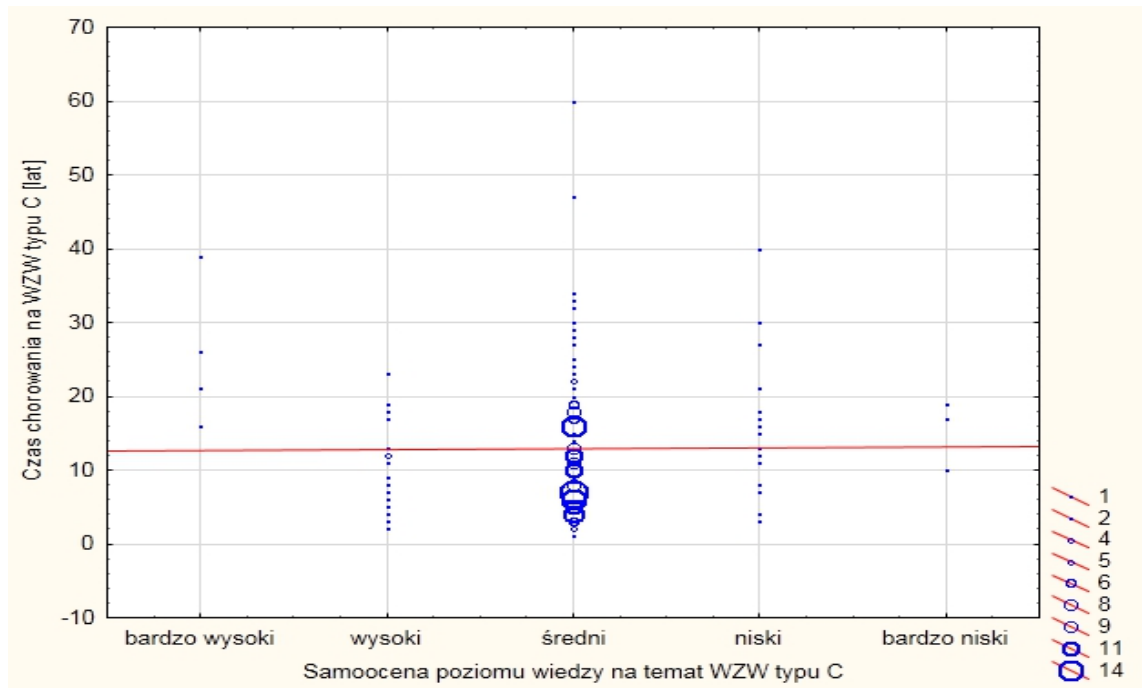

Figure 3. Distribution of respondents' duration of the disease according to levels of self-reported knowledge concerning hepatitis $\mathrm{C}$.

The largest number of respondents indicated that their knowledge concerning hepatitis $\mathrm{C}$ was on a mediocre level $-72.7 \%$ (160), and the mean duration of the disease was 12.5 years. The shortest duration of the disease reported was 1 year, while the longest - 60 years; median -11.0 years. The respondents who mentioned a 'high' level of knowledge concerning hepatitis $\mathrm{C}(12.3 \%, 27)$ occupied the second position, with the mean duration of the disease 10,1 years, followed by those who indicated a 'low' level $(11.4 \%, 25)$; the mean duration of the disease -14.8 years. In few respondents $(2.3 \%, 5)$, with a 'very high' level of knowledge concerning hepatitis $\mathrm{C}$, the mean duration of the disease was 25.6 years. A 'very low' level of 
knowledge concerning hepatitis $\mathrm{C}$ was reported by $1.4 \%$ of respondents (3); the mean duration of the disease was 15.3 years. The relationships were statistically insignificant ( $\mathrm{p}>0.05)$, and the correlation was slightly positive $(\mathrm{R}=0.04)$.

Each respondent was asked about the feeling of being a disabled person due to HCV infection - Tab. 6, Fig.4.

Table 6. Respondents' self-reported feeling of being disabled due to HCV infection.

\begin{tabular}{|c|c|c|}
\hline \multicolumn{2}{|c|}{$\begin{array}{c}\text { Well-being of respondents } \\
\text { infected with HCV from the } \\
\text { aspect of disability: }\end{array}$} & Total \\
\hline \multirow{2}{*}{ Yes } & $\mathrm{n}$ & 47 \\
\cline { 2 - 3 } & $\%$ & $21.4 \%$ \\
\hline \multirow{2}{*}{ No } & $\mathrm{n}$ & 173 \\
\cline { 2 - 3 } & $\%$ & $78.6 . \%$ \\
\hline \multirow{2}{*}{ Total } & $\mathrm{n}$ & 220 \\
\cline { 2 - 3 } & $\%$ & 100.0 \\
\hline
\end{tabular}

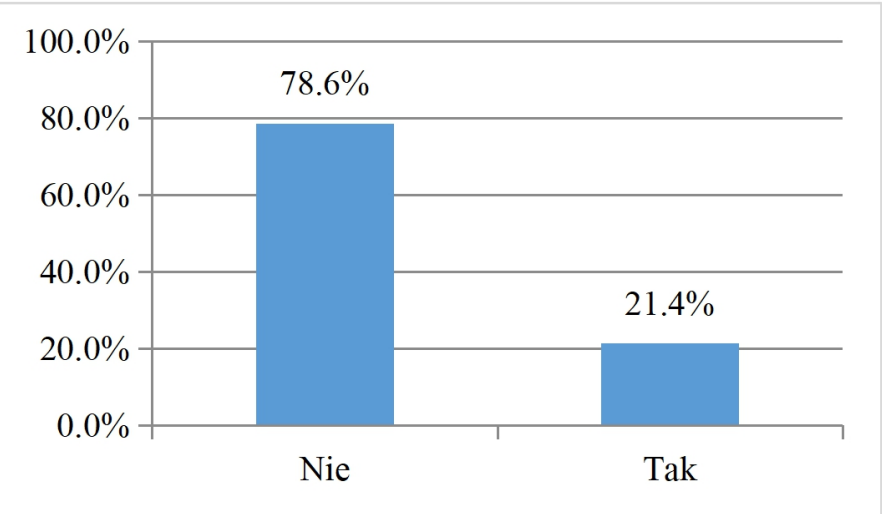

Figure 4. Frequency of self-reported feeling of being disabled due to HCV infection.

The largest number of respondents reported that they did not feel disabled due to HCV infection $(78.6 \%, 173)$. Approximately $1 / 5$ of the patients in the study $(47 ; 21.4 \%)$ admitted that they considered themselves to be disabled. This group of respondents most often manifested reluctance to disclose their illness.

Analysis of the collected research material covered also assessment of friendly atmosphere in the respondent's family (Tab.7). 
Table 7. Respondents' assessment from the aspect of friendly atmosphere in a family.

\begin{tabular}{|c|c|c|}
\hline \multicolumn{2}{|c|}{$\begin{array}{c}\text { Frequency of friendly } \\
\text { atmosphere in a family of a } \\
\text { person infected with HCV }\end{array}$} & \multirow{2}{*}{ Total } \\
\hline \multirow{2}{*}{ always } & $\mathrm{n}$ & 80 \\
\cline { 2 - 3 } & $\%$ & $36.4 \%$ \\
\hline \multirow{2}{*}{ frequently } & $\mathrm{n}$ & 99 \\
\cline { 2 - 3 } & $\%$ & $45.0 \%$ \\
\hline \multirow{2}{*}{ rarely } & $\mathrm{n}$ & 23 \\
\hline \multirow{2}{*}{ never } & $\%$ & $10.5 \%$ \\
\hline \multirow{2}{*}{ not applicable, I live on my } & $\mathrm{n}$ & 2 \\
\hline own & $\%$ & $0.9 \%$ \\
\hline \multirow{2}{*}{ Total } & $\mathrm{n}$ & 16 \\
\hline & $\mathrm{n}$ & $7.3 \%$ \\
\cline { 2 - 3 } & $\%$ & 220 \\
\hline
\end{tabular}

Table 7 shows that the largest number of respondents with hepatitis C (99; 45\%) reported that a friendly atmosphere 'frequently' prevailed in their family, followed by those who mentioned 'always' $(80 ; 36.4 \%)$, and 'rarely' $-10.5 \%$ of respondents $(23)$.

\section{Summing up}

In systematic literature reviews reports are encountered concerning various circumstances of contracting $\mathrm{HCV}$ infection [8,9.10]. Therefore, this problem was an incentive to undertake the presented study in order to recognize the circumstances of $\mathrm{HCV}$ infection in adult Polish population.

Own study showed that adults infected with HCV most frequently did not know the circumstances of infection (62.7\%). The remaining respondents (37.3\%) reported the circumstances in which the infection with $\mathrm{HCV}$ might have occurred, primarily the main treatment entities, while few respondents mentioned 'other circumstances' where the transmission of blood-borne infections takes place.

Approximately $3 / 4$ of respondents had a 'mediocre' level of knowledge concerning the essence of chronic hepatitis $\mathrm{C}$, while $11.4 \%$ of the infected persons mentioned a 'low' level of this knowledge, which is associated with the risk of the lack of observance of recommendations concerning health promoting life style. The results obtained concerning the self-reported level of knowledge on hepatitis $\mathrm{C}$ according to the respondents' mean age and the mean duration of the disease were statistically insignificant $(p>0.05)$.

Considering the above-presented epidemiological problems there is a need for intensification of health education among Polish adult population. In addition, school 
adolescents should be motivated to expand their knowledge of the problem of prevention of hepatitis $\mathrm{C}$ virus infection, the sources of infection with $\mathrm{HCV}$, with particular consideration of drug addicts and the places of transmission of blood-borne infections (beauty parlours, hairdressers) [11].

\section{Conclusions:}

1. Persons with chronic hepatitis $\mathrm{C}$ most often did not know the circumstances of contracting $\mathrm{HCV}$ infection.

2. More than $1 / 3$ of the respondents reported circumstances in which $\mathrm{HCV}$ infection might have taken place - primarily in a hospital in association with a surgical procedure, conservative treatment, childbirth, organ transplantation, dialysis, blood transfusion, and plasmapheresis. Other circumstances which could have caused the infection were: dental treatment, occupational exposure, tattoo, and narcotic injection.

3. The majority of patients infected with $\mathrm{HCV}$ had a mediocre level of knowledge concerning hepatitis $\mathrm{C}$.

4. The largest number of respondents did not consider themselves to be disabled to hepatitis C.

5. The results of the study confirm the need for educating the Polish population in the area of risky circumstances of infection with $\mathrm{HCV}$, and the essence of chronic hepatitis $\mathrm{C}$.

\section{References}

1. Global health sector strategy on viral hepatitis 2016-2021. Word Health Organization 2016; $1-56$.

2. Sierpińska L. Hepatitis $\mathrm{C}$ as a health problem in Poland. Jacobs Journal of Nursing and Care 2015; 1(1): 1-5.

3. Stępień M, Rosińska M. Ogniska wirusowego zapalenia wątroby typu $\mathrm{C} w$ Polsce w latach 2003-2013. Procedury medyczne najczęstszą drogą przenoszenia zakażeń HCV. Przegląd Epidemiologiczny 2015; 69(3): 585-590.

4. Tomasiewicz K. et al. Współczesne poglądy na zagadnienie możliwości transmisji wirusa zapalenia wątroby typu $\mathrm{C}$ w placówkach opieki medycznej. HEPATOLOGIA 2015; 15: 60-64.

5. Flisiak $\mathrm{R}$ et al. Prevalence and riskfactors of $\mathrm{HCV}$ infection in Poland. Eur $\mathrm{J}$ Gastroenterol Hepatol 2011; 23(12): 1213-7.

6. Godzik P. et al. Rozpowszechnienie przeciwciał anty-HCV wśród osób dorosłych w Polsce - wyniki badania przekrojowego w populacji ogólnej. Przegląd Epidemiologiczny 2012; 66(4): 575-580.

7. Chen SL., Morgan TR. The natural history of hepatitis $\mathrm{C}$ virus (HCV) infection. International Journal of Medical Sciences 2006; 3(2): 47-52

8. Zakrzewska K, Stępień M, Rosińska M. Wirusowe zapalenie wątroby typu C (wzw C) w Polsce w 2017 roku. Przegląd Epidemiologiczny 2019; 73(2): 167-178. 
9. Sakem B, Madaliński K, Nydegger U, et al. Hepatitis C virus epidemiology and prevention in Polish and Swiss population - similar and contrasting experiences. Annals of Agricultural and Environmental Medicine 2016; 23(3): 425-431.

10. Goniewicz M, Włoszczak-Szubzda A, Niemcewicz M, et al. Injuries caused by sharp instruments among healthcare wolkers - international and Polish perspectives. Annals of Agricultural and Environmental Medicine 2012;19(3): 523-527.

11. Sierpińska L., Chrapko M., Rząca M. Ocena stanu wiedzy młodzieży na temat zakażenia wirusem HCV. Aspekty Zdrowia i Choroby 2018; 3(1): 97-108. 